University of Nebraska - Lincoln

DigitalCommons@University of Nebraska - Lincoln

1994

\title{
Serum Cholesterol Concentration of Mice Selected for Litter Size and its Relationship to Litter Size and Testis Mass
}

\author{
E. L. de A. Ribeiro \\ Londrina, Brazil \\ R. J. Kittok \\ University of Nebraska-Lincoln, rkittok1@aol.com \\ Merlyn K. Nielsen \\ University of Nebraska-Lincoln, mnielsen1@unl.edu
}

Conselho Nacional de Desenvolvimento Cientifico e Tecnologico (CNPq) and Universidade Estadual de

Follow this and additional works at: https://digitalcommons.unl.edu/animalscifacpub

Part of the Animal Sciences Commons

de A. Ribeiro, E. L.; Kittok, R. J.; and Nielsen, Merlyn K., "Serum Cholesterol Concentration of Mice Selected for Litter Size and its Relationship to Litter Size and Testis Mass" (1994). Faculty Papers and Publications in Animal Science. 494.

https://digitalcommons.unl.edu/animalscifacpub/494

This Article is brought to you for free and open access by the Animal Science Department at DigitalCommons@University of Nebraska - Lincoln. It has been accepted for inclusion in Faculty Papers and Publications in Animal Science by an authorized administrator of DigitalCommons@University of Nebraska - Lincoln. 


\title{
Serum Cholesterol Concentration of Mice Selected for Litter Size and its Relationship to Litter Size and Testis Mass ${ }^{1}$
}

\author{
E. L. de A. Ribeiro ${ }^{2}$, R. J. Kittok, and M. K. Nielsen ${ }^{3}$ \\ Department of Animal Science, University of Nebraska-Lincoln, Lincoln 68583-0908
}

\begin{abstract}
This study assessed the genetic relationship between litter size and serum cholesterol concentration and between litter size and testis mass in mice. Mice were from a long-term experiment in which selection had occurred for 21 generations in three replicated lines per criterion of selection ( $\mathrm{LS}=$ selection to increase litter size based on number born; LC = unselected control). Thereafter, random mating within lines was practiced. Serum cholesterol concentrations were evaluated in female and male mice from two replicates at Generation 29 and one replicate at Generation 30. Body weights and blood samples were collected from primiparous females $8 \mathrm{~d}$ after weaning their pups. Data from males were collected as they came out of breeding cages. In addition, the testes were excised, stripped clean of connective tissue and
\end{abstract}

the epididymides, and weighed. Means for body mass of females and males, serum cholesterol, number born, and testis mass were as follows: 35.2 vs $32.5 \mathrm{~g}(P<$ .09 ), 33.9 vs $30.7 \mathrm{~g}(P<.08), 117.5 \mathrm{vs} 110.5 \mathrm{mg} / \mathrm{dL}$ ( $P$ $<.08), 14.0$ vs 10.3 pups $(P<.04)$, and 126 vs 122 $\mathrm{mg}$, respectively, for LS and LC. Serum cholesterol was greater in males than in females (133.3 vs 95.1 $\mathrm{mg} / \mathrm{dL} ; P<.001$ ), but there was no interaction between sex and selection criterion. Serum cholesterol concentration was not correlated phenotypically to number born or body mass, but it had a small negative relationship with testis mass. Therefore, we concluded that selection for litter size tended to increase serum cholesterol in addition to the increase in number born but did not change testis mass.

Key Words: Mice, Cholesterol, Litter Size, Testis Mass, Body Mass

J. Anim. Sci. 1994. 72:2943-2947

\section{Introduction}

The effects of serum cholesterol on reproduction are unclear. Young et al. (1993) and Wise et al. (1993) reported that ovulation rate and litter size were less in a line of pigs selected for high cholesterol concentration than either pigs in a line selected for low cholesterol or in an unselected line. However, Dunnington et al. (1981b) found no association between number of pups alive at $5 \mathrm{~d}$ and serum cholesterol after five generations of divergent selection for serum cholesterol concentration in mice. The response in serum cholesterol concentration after selection for litter size or ovulation rate has not been studied. Therefore, the primary hypothesis for this study was

\footnotetext{
${ }^{1}$ Published as paper no. 10353, Journal Series, Nebraska Agric. Res. Div., Lincoln.

${ }^{2}$ Supported by Conselho Nacional de Desenvolvimento Cientifico e Tecnologico (CNPq) and Universidade Estadual de Londrina, Brazil.

${ }^{3}$ To whom correspondence should be addressed: A218 Animal Science.

Received April 25, 1994.

Accepted July 8, 1994.
}

that serum cholesterol is lower in mice selected for increased litter size than in control mice.

Land (1973) postulated that testis size may be correlated with ovarian activity of genetically related females because the same gonadotropic hormones (FSH and LH) are present in both sexes of mammals. This relationship is supported by several reports in mice (Islam et al., 1976; Eisen and Johnson, 1981; and Hill et al., 1990). However, Eckardt (1989) found no correlated change in ovulation rate of swine selected six generations for increased paired testes mass. Therefore, a secondary hypothesis of the present study was that the testes of male mice selected for litter size would be larger than for males with no selection history.

\section{Materials and Methods}

Source of Mice

A total of 384 mice were used in this study. They were sampled from lines of mice selected to increase litter size based on number born ( $\mathbf{L S}$ ) and contemporary unselected control lines (LC). Details of the development of selection methods were described by 
Clutter et al. (1990). Selection occurred for 21 generations in three independent replicates per selection criterion. Thereafter, relaxed (i.e., no intentional) selection was practiced with females mated only to males of their same line.

The three replicates were separated in their life cycles by $4 \mathrm{wk}$, with contemporary LS and LC lines within a replicate. Results for ovulation rate and litter size from 13 generations of selection were evaluated by Gion et al. (1990), and responses for litter size through 21 generations plus six subsequent generations of relaxed selection were reported by Kirby and Nielsen (1993). No changes have been observed in litter size during the generations of relaxed selection, and the difference (LS minus LC) was 4.1 pups for number born (Kirby and Nielsen, 1993). The difference (LS minus LC) in ovulation rate at Generations 22 and 23 was 3.0 ova (Clutter et al., 1994).

The data in this study were collected from mice of both selection criteria (LS and LC) in all three replicates: two replicates at Generation 29 and one replicate at Generation 30. Thirty-two males and 32 females were used from each of the six lines. The 64 mice from each line were the offspring of 32 litters, one male and one female drawn from each litter.

\section{Animal Management and Data Collection}

Mice had ad libitum access to water and feed. Diets for the mice for $4 \mathrm{wk}$ before sample collection were as follows: $4.25 \mathrm{kcal} / \mathrm{g}$ of gross energy, $20 \%$ crude protein, $10 \%$ fat, and $2 \%$ crude fiber (Diet 8626, Harlan Teklad, Madison, WI) for female mice; $3.93 \mathrm{kcal} / \mathrm{g}$ of gross energy, $24 \%$ crude protein, $4 \%$ fat, and $4.5 \%$ crude fiber (Diet 8604, Harlan Teklad) for male mice. They were housed in rooms with lighting controlled to provide $12 \mathrm{~h}$ of light (from 0700 to 1900 ) per day. Room temperature was maintained at approximately $24^{\circ} \mathrm{C}$. Females were paired with males at 9 wk of age in mating cages, and matings were assigned to minimize inbreeding. After recording number born, all litters with more than eight pups were reduced to eight pups within $1 \mathrm{~d}$ after birth. Litters of less than eight pups were not augmented with extra pups.

At an average age of $16 \mathrm{wk}$, and $8 \mathrm{~d}$ after weaning their pups, females were administered carbon dioxide until apparent asphyxiation. Each mouse was quickly weighed, and a blood sample was drawn by cardiac puncture. All blood samples for serum cholesterol assay were drawn in the morning between 0900 and 1100. The same procedure was followed for males after they came out of the breeding cages, at an average age of $12 \mathrm{wk}$. In addition, the testes were excised, stripped clean of connective tissue, and the epididymides, and the right and left testes were weighed separately.

The blood samples were allowed to clot at room temperature for $6 \mathrm{~h}$ and then stored at $4^{\circ} \mathrm{C}$ for $24 \mathrm{~h}$. Then the samples were centrifuged $(15,600 \times \mathrm{g}$ for 10 min), and the serum portions were harvested and frozen $\left(-20^{\circ} \mathrm{C}\right)$ until cholesterol was assayed. Serum cholesterol was determined enzymatically with the methods of Allain et al. (1974). Briefly, cholesterol esters from the samples were catalyzed with cholesterol esterase, and then the free cholesterol was oxidized in the presence of cholesterol oxidase. The resulting hydrogen peroxide reacted with 4 -aminoantipyrine and $p$-hydroxybenzoate-producing red quinoneimine (reagents were obtained from Gilford Systems, Oberlin, $\mathrm{OH}$ ). The intensity of the color produced was directly proportional to the amount of cholesterol in the sample and was detected spectrophotometrically at a wavelength of $500 \mathrm{~nm}$ (Model UV-260, Shimadzu, Columbia, MD). The lower limit of detection of the assay was less than $10 \mathrm{mg} / \mathrm{dL}$. Intra- and interassay CV were 5.2 and $6.5 \%$, respectively.

\section{Statistical Analyses}

Cholesterol concentration was analyzed with least squares (GLM procedures of SAS, 1989) using a model that included the fixed effects of selection criterion and sex, and the random effect of replicate, and all possible two- and three-way interactions. The main-plot experimental units were the lines of mice; hence, selection criterion, replicate, and their interaction were the main-plot terms in the analysis of variance. Effect of selection criterion was tested with the interaction of replicate $\times$ selection criterion as the error term. Mice were the subplot experimental units. The interaction of sex $\times$ selection criterion was tested with the interaction of sex $\times$ replicate $\times$ selection criterion. The effect of sex was tested using the subplot residual (mice/replicate-selection criterionsex) source of variation as the error term.

Number of pups born and body mass (each sex separately) were analyzed using a model with the main effects of replicate and selection criterion, and the interaction of replicate $\times$ selection criterion. In the analysis of variance, selection criterion was tested using the interaction of replicate $\times$ selection criterion as the error term. The model for analysis of single testis was also a split-plot with fixed effects of selection criterion and side, and the random effect of replicate, and all two- and three-way interactions. The main-plot effects were handled as described for cholesterol concentration. A single testis was the experimental unit for the subplot, and side $\times$ criterion was tested with side $\times$ replicate $\times$ selection criterion, and side was tested using the testes/replicate-selection criterion-side source of variation.

The phenotypic correlation between cholesterol concentration and body mass was pooled within replicate-selection criterion-sex, and all other correlations were pooled within replicate-selection criterion classes. 


\section{Results}

Means and $\mathrm{CV}$ according to selection criterion for body mass, serum cholesterol concentration, number of pups born, and testis mass are presented in Table 1. Coefficients of variation ranged from approximately $7 \%$ for body mass to approximately $20 \%$ for number born. Serum cholesterol concentration tended to be greater $(P<.08)$ in mice selected for litter size than in controls. Females in the LS selection criterion had a greater number of pups born $(P<.04)$ than those in the LC criterion and tended to have heavier body weights $(P<.09)$. Testis mass in males did not differ $(P>.10)$ between the two selection criteria, even though body mass tended to be different $(P<.08$ ). However, there also were no differences ( $\mathrm{LS}=3.7$ and $\mathrm{LC}=4.0 \mathrm{mg} / \mathrm{g} ; P>.10$ ) in testis mass per unit of body mass between selection criteria. Females were heavier than males, but they were an average of $4 \mathrm{wk}$ older and had weaned one litter when body mass was measured.

The interaction of sex $\times$ selection criterion was not significant for serum cholesterol concentration. Serum cholesterol concentration was greater in males than in females ( 133.3 vs $95.1 \mathrm{mg} / \mathrm{dL}, P<.001)$. The selection criterion-sex means were as follows: LS females, 100.1; LC females, 90.1; LS males, 135.0; and LC males, $131.7 \mathrm{mg} / \mathrm{dL}$.

Phenotypic correlations, pooled within replicateselection criterion classes, did not differ between criteria (Figure 1). Phenotypic correlations between serum cholesterol concentration and number of pups born and between serum cholesterol concentration and body mass were essentially zero. There was a slightly negative $(P<.10)$ correlation between serum cholesterol concentration and testis mass. Phenotypic correlations between body mass and testis mass, and between body mass and number of pups born were significant and positive.

\section{Discussion}

After eight generations of relaxed selection, litter size for females of the LS lines was still greater than that for females of the LC lines. This difference (3.7 pups) agrees with a previous report of the average advantage in litter size for the LS over the LC (4.1 pups) during the first six generations of relaxed selection (Kirby and Nielsen, 1993).

Selection for number of pups born tended to increase the serum cholesterol concentration (approximately $6 \%$ ), but the phenotypic correlation between these two traits was almost zero and not significant (Figure 1). This lack of phenotypic correlation agrees with Dunnington et al. (1981b), who did not find an association between reproductive traits (number of pups alive at $5 \mathrm{~d}$, percentage of females littering, and average littering interval) and cholesterol concentration in mice.

Conversely, a line of pigs selected for low serum cholesterol concentration had a greater ovulation rate than did a contemporary line selected for high serum cholesterol concentration (Young et al., 1993). However, differences in number of fetuses between those lines of pigs were not significant. Also, the percentage of gilts reaching puberty by $9.5 \mathrm{mo}$ of age was less for gilts selected for low cholesterol concentration than either gilts selected for high cholesterol concentration or for unselected gilts. Wise et al. (1993) reported that the larger litter size in the line selected for low serum cholesterol was related to alterations in pituitary and gonadal secretory functions. The gonadal steroid concentrations were decreased and FSH was increased in pigs of the low serum cholesterol line compared with those of the high serum cholesterol line.

The lack of phenotypic correlation between body mass and serum cholesterol concentration agrees with the findings of Dunnington et al. (1977), but it is in contrast to those of Eapen et al. (1971). Phenotypic correlations between body mass and serum cholesterol concentration of .37 for females and .45 for males were reported (Eapen et al., 1971). The genetic relationship seems to be positive and the environmental relationship negative between body mass and serum cholesterol, thus explaining phenotypic correlation estimates near zero. Mice of the LS selection criterion tended to be larger in size and have greater serum cholesterol than mice from LC. This agrees with the data of Dunnington et al. (1981b) that mice selected for either high or low serum cholesterol had correlated responses in body weights in the same directions. Also, Young et al. (1993) reported that pigs selected for greater serum cholesterol were also heavier than those in the control line and the line selected for lower serum cholesterol.

Selection for litter size did not affect testis mass in the present study. The difference between the LS and LC selection criteria was only $3 \%(P>.10)$. This result does not agree with mouse studies by Land (1973), Joakimsen and Baker (1977), and Eisen and Johnson (1981). These studies found a correlated response in testis mass following selection for ovulation rate or litter size. A positive response of increased ovulation rate after testis size selection was reported by Hill et al. (1990); selection for larger testis size produced a positively correlated response in litter size. However, Islam et al. (1976) found that selection for larger testes in mice did not result in a change in litter size, even though there was a correlated response in ovulation rate. Eckardt (1989) also did not find a correlated response in ovulation rate of swine selected for larger predicted mass (index of width and length of paired testes) of testes. In the present study, the genes controlling litter size, the frequency of which have been modified by selection, seem to be different 
Table 1. Least squares means, tests of criterion differences, and coefficients of variation for body mass, serum cholesterol, number of pups born, and testis mass in mice either selected for larger litter size or not selected

\begin{tabular}{lccccc}
\hline \hline & $\begin{array}{c}\text { Female } \\
\text { body } \\
\text { mass, g }\end{array}$ & $\begin{array}{c}\text { Male } \\
\text { body } \\
\text { mass, g }\end{array}$ & $\begin{array}{c}\text { Serum } \\
\text { cholesterol } \\
\text { mg/dL }\end{array}$ & $\begin{array}{c}\text { No. } \\
\text { born }\end{array}$ & $\begin{array}{c}\text { Testis } \\
\text { mass, } \\
\text { mg }^{\mathrm{b}}\end{array}$ \\
\hline Item & & & & & \\
Selection criterion & & & & & \\
LC & 32.5 & 30.7 & 110.5 & 10.3 & 122 \\
LS & 35.2 & 33.9 & 117.5 & 14.0 & 126 \\
Probability & .09 & .08 & .08 & .04 & .70 \\
CV, \% & 6.6 & 8.6 & 17.5 & 19.8 & 10.0 \\
\hline
\end{tabular}

${ }^{a}$ Means for serum cholesterol are across both sexes.

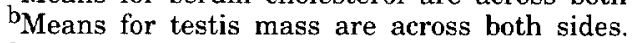

${ }^{c} \mathbf{L C}=$ no selection control; $\mathbf{L S}=$ selection for litter size.

${ }^{\mathrm{d}}$ Probability of significant difference.

from those controlling testis size. The positive phenotypic correlation (.30) between body mass and testis mass is the same as reported by Eisen and Johnson (1981).

Right testes were approximately $6 \%$ heavier than left testes $(P<.001)$. This was consistent with differences between sides in ovulation rate in the same population. In the base population (Clutter et al., 1990), and at Generation 13 (Gion et al., 1990), Generations 22 and 23 (Clutter et al., 1994), and Generation 27 (Al-Shorepy et al., 1992), greater means were consistently observed for the right vs left side for ovulation rate, ova success, and number of fetuses.

Serum cholesterol concentrations were $29 \%$ greater in males than in females even though males were fed a diet with less fat than the diet given to females. This difference between sexes agrees with previous reports. Weibust (1973) stated that one possible explanation for the sex difference in cholesterol concentration can be found in the action of estrogens. Cholesterol concentrations for males and females (133.3 and 95.1 $\mathrm{mg} / \mathrm{dL}$ ) were greater than the values reported by Dunnington et al. (1981a) in the control line of their selection experiment for cholesterol. However, the values in the present study were just 63 and $50 \%$ of the values reported by Eapen et al. (1971) for males and females, respectively. Weibust (1973) also reported greater values.

Selection for number of pups born tended to increase body mass. Mice from the LS selection criterion were approximately $8.5 \%$ heavier than mice from the LC criterion. Other selection experiments for increased ovulation rate or litter size had positively correlated responses for body mass (Land, 1973; Joakimsen and Baker, 1977; Eisen, 1978). However, Bakker et al. (1978) did not find a correlated response in body mass at $56 \mathrm{~d}$ in a line of mice selected for increased litter size. In that study, litters were not standardized for rearing compared with the present study in which litters were standardized. Thus, any positive genetic response in body mass may have been confounded with a counteracting negative maternal effect when mice are reared in larger litters.

The positive phenotypic correlation (.26) between body mass and number of pups born agrees with the value (.27) reported by Eisen (1978). Realized genetic correlations in the literature range from .52 to .62 and are generally greater than phenotypic correlations (Joakimsen and Baker, 1977; Eisen, 1978; Eisen and Johnson, 1981). However, Bakker et al. (1978) reported a realized genetic correlation of .06 , which was not different from zero.

In summary, the results of this work do not support the primary hypothesis that mice selected for increased litter size have lower serum cholesterol concentrations than unselected mice. The mice from lines selected for larger litter size tended to have greater serum cholesterol. Likewise, we found no support for the secondary hypothesis that male mice from lines selected for litter size have larger testes.

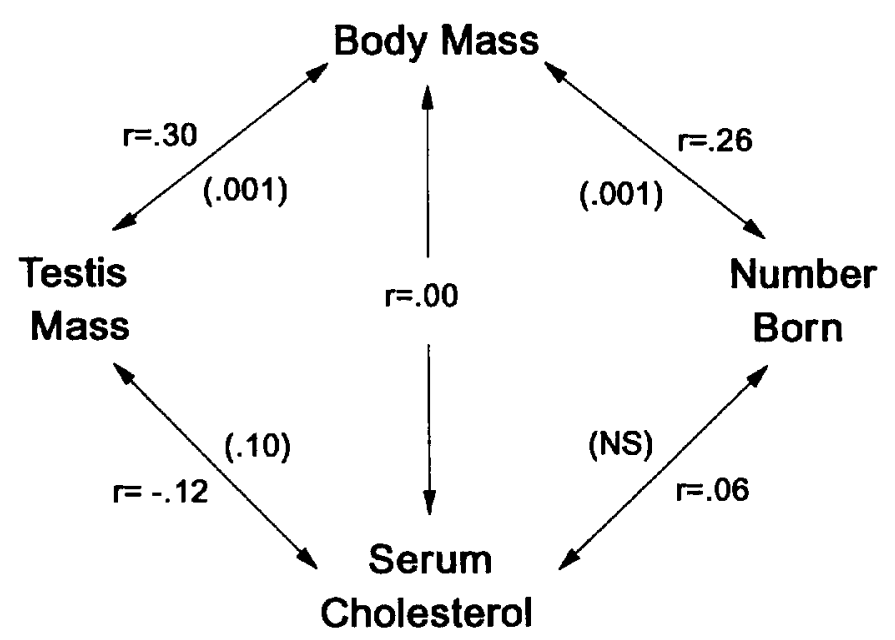

Figure 1. Phenotypic correlations between body mass, serum cholesterol, testis mass, and number born. Level of significance, shown in (), for the correlation, $r$. NS = not significant. 
There was no significant difference in testis mass between selected and unselected lines. Conflicting results between studies with mice and between studies with mice and pigs exist. There are no clear explanations for these conflicts.

\section{Implications}

No large responses in reproduction of mice are expected with changes in serum cholesterol concentration. However, the relationship between serum cholesterol concentration and litter size seems to be different in mice than in swine. The relationship between testis mass and litter size is not consistent across different studies with mice and is not apparent in swine.

\section{Literature Cited}

Allain, C. C., L. S. Poon, C.S.G. Chan, W. Richmong, and P. C. Fu. 1974. Enzymatic determination of total serum cholesterol. Clin. Chem. 20:470.

Al-Shorepy, S. A., A. C. Clutter, R. M. Blair, and M. K. Nielsen. 1992. Effects of three methods of selection for litter size in mice on pre-implantation embryonic development. Biol. Reprod. 46: 958.

Bakker, H., J. H. Wallinga, and R. D. Politiek. 1978. Reproduction and body weight of mice after long-term selection for larger litter size. J. Anim. Sci. 46:1572.

Clutter, A. C., Y. L. Kochera Kirby, and M. K. Nielsen. 1994. Uterine capacity and ovulation rate in mice selected 21 generations on alternative criteria to increase litter size. J. Anim. Sci. 72:577.

Clutter, A. C., M. K. Nielsen, and R. K. Johnson. 1990. Alternative methods of selection for litter size in mice: I. Characterization of base population and development of methods. J. Anim. Sci. 68:3536.

Dunnington, E. A., J. M. White, and W. E. Vinson. 1977. Serum cholesterol, activity, feed intake, and body weight in lines of mice selected for growth. Can. J. Genet. Cytol. 19:415.
Dunnington, E. A., J. M. White, and W. E. Vinson. 1981a. Selection for serum cholesterol, voluntary physical activity, 56-day body weight and feed intake in random bred mice. I. Direct responses. Can. J. Genet. Cytol. 23:533.

Dunnington, E. A., J. M. White, and W. E. Vinson. 1981b. Selection for serum cholesterol, voluntary physical activity, 56-day body weight and feed intake in random bred mice. II. Correlated responses. Can. J. Genet. Cytol. 23:545.

Eapen, K. J., O. B. Goswami, and S. K. Pillai. 1971. Inheritance of serum cholesterol and its relation to body weight in white mice. J. Genet. 60:222.

Eckardt, G. R. 1989. Responses to six generations of selection for increased size of testes in swine. M.S. Thesis. University of Nebraska, Lincoln.

Eisen, E. J. 1978. Single-trait and antagonistic index selection for litter size and body weight in mice. Genetics 88:781.

Eisen, E. J., and H. Johnson. 1981. Correlated responses in male reproductive traits in mice selected for litter size and body weight. Genetics 99:513.

Gion, J. M., A. C. Clutter, and M. K. Nielsen. 1990. Alternative methods of selection for litter size in mice: II. Response to thirteen generations of selection. J. Anim. Sci. 68:3543.

Hill, W. G., P. J. Marks, J. C. Jenkins, and R. B. Land. 1990. Selection on testis size as an indicator of maturity in growing animals: II. Correlated responses. Genet. Sel. Evol. 22:247.

Islam, A.B.M.M., W. G. Hill, and R. B. Land. 1976. Ovulation rate of lines of mice selected for testis weight. Genet. Res, 27:23.

Joakimsen, O., and R. L. Baker. 1977. Selection for litter size in mice. Acta Agric. Scand. 27:301.

Kirby, Y. K., and M. K. Nielsen. 1993. Alternative methods of selection for litter size in mice: III. Response to 21 generations of selection. J. Anim. Sci. 71:571.

Land, R. B. 1973. The expression of female sex-limited characters in the male. Nature (Lond.) 241:208

SAS. 1989. SAS/STAT $\left.{ }^{(}\right)$User's Guide. SAS Inst. Inc., Cary, NC.

Weibust, R. S. 1973. Inheritance of plasma cholesterol levels in mice. Genetics 73:303.

Wise, T., L. D. Young, and W. G. Pond. 1993. Reproductive, endocrine, and organ weight differences of swine selected for high or low serum cholesterol. J. Anim. Sci. 71:2732.

Young, L. D., W. G. Pond, and H. J. Mersmann. 1993. Direct and correlated responses to divergent selection for serum cholesterol concentration on day 56 in swine. J. Anim. Sci. 71: 1742. 